\title{
Effectiveness of Public Spending before and during COVID-19 Pandemic
}

\author{
Kamelia Assenova \\ Department of Economics, University of National and World Economy Sofia, Bulgaria \\ E:mail:kamelia_a@yahoo.com
}

Received: 17 May 2021; Revised: 20 August 2021; Accepted: 28 December 2021

\begin{abstract}
The pandemic of COVID-19 influences all sectors of the economy. It caused decreasing in produced Gross domestic product (GDP) and higher unemployment. As it is known, to overcome this negative tendency, it is possible to put in practice monetary and fiscal instruments. During the pandemic, the government tried to slow down negative economic results through public spending. With them, the government looks to be increased aggregate demand in the economy and as a result-GDP raises and unemployment reduces. The research is based on created original model for testing the impact of total public spending, capital, salary, social insurance and care, for maintenance by a consolidated fiscal program on the value of GDP. The changes of GDP measure the effectiveness of public spending. The period of research is before and during the COVID-19 crisis (2019-2020) in the case of Bulgaria. Before the pandemic the analysis shows coefficient of determination for capital spending is more significant compare with all other types of public expenditure and these cost predetermine economic growth. During the pandemic of COVID-19 public spending has used as the main instrument to overcome the negative results for the economy. For this period it found an extremely strong impact of labor costs and social care expenditure on aggregate demand. They bring more positive results to be solved health issues, but not for faster recovery of the economy.
\end{abstract}

Keywords: COVID-19, public spending, GDP growth, regression model

JEL Code: H50, E62, C13

\section{Introduction}

The pandemic of COVID-19 influences all sectors of the economy. From one side, in response to the pandemic countries all over the world have offered large fiscal support packages to save lives and protect households and firms. More economies have provided large fiscal support to households and firms. These policies have mitigated the pandemic's impact on consumption and output. The public expenditure aims: liquidity support for firms, preventing unemployment and support for the unemployed. On the other side, the economy needs a quick and full recovery. COVID-19 crises caused decreasing in produced GDP and higher unemployment. During the pandemic, the government tried to slow down negative economic results through public spending. With them, it looks to be increased directly

Copyright (C2022 Kamelia Assenova.

DOI: https://doi.org/10.37256/ges.232021942

This is an open-access article distributed under a CC BY license

(Creative Commons Attribution 4.0 International License)

https://creativecommons.org/licenses/by/4.0/ 
aggregate demand in the economy and as a result-GDP and reduce the unemployment.

The fiscal measures to overcome every recession include a mix of rising public spending and tax cuts (mainly direct income). An increasing public spending has a direct effect on the economy, because higher demand for goods and services. As a result, income and employment increase not only in the sectors where public spending is taking place. Its movement stimulates consumer spending, due to the higher purchasing power of the household. The empirical data indicates increased public spending has a stronger effect on the stage of the economy than tax cuts.

The present study researches public spending and its impact on economic activities for Bulgaria before and during the pandemic of COVID-19.

As has been written above, public spending has a direct effect on aggregate demand and on the volatility of GDP. This research will test the degree of impact of public spending of the consolidated fiscal program on GDP. The correlation will be examined for public spending total, for capital, for salary, social insurance and care, for maintenance (according to the classification of the consolidated fiscal program). Some of them have a direct and multiplier effect on aggregate demand and another-indirect-via consumer spending and their impact could be lower.

\section{Literature review}

During the COVID pandemic, the governance in every country took care for the health care system, functioning of the market, support for business and households. It increased public spending to meet these needs. Public expenditure has increased in many countries for decades. The COVID-19 crisis contributed to further increases in government expenditure. The effective public spending is a result of determining the outcomes of the government performance in responding to natural disasters, pandemics and other crises are well documented in the literature (Kahn, 2005; Raschky, 2008; Lin, 2015).

The research evidence on South Korea explains that public spending during to COVID-19 pandemic were needed to combat the pandemic in the short term, but these responses may have long-term consequences for fiscal sustainability (Kim, 2020).

The main part of public spending was directed to business. "The human and economic devastation caused by COVID-19 provides a strong rationale for temporary government support for firms. Some sectors have been hit particularly hard (e.g. airlines, restaurants), but the damage is propagating throughout all sectors and economies as restrictions on movement weigh on activity. The lack of government support could lead to an even deeper and prolonged recession and be highly disruptive to the functioning of businesses and the lives of workers. Fiscal support can address firms' liquidity needs and encourage them to preserve employment and wages. In the more vulnerable sectors, firms may also face insolvency challenges as the crisis deepens. A key objective is to avoid long-term effects from bankruptcies, downsizings, or asset liquidations (Balibek et al., 2021).

Barnichon et al. (2020) also observed public spending and show that the direction of the fiscal intervention is an important overlooked determinant of the spending multiplier and recovery of the economy.

\section{Problem statement}

During the pandemic of COVID-19 Bulgarian government took decisions for following expenditure measures (European Commission Directorate General Economic and Financial Affairs Policy, 2020):

- Additional expenditure in the amount of up to BGN 17.6 million (EUR 7.3 million) was approved under the budget of the Ministry of Health for 2020 to ensure preparedness for preventive and anti-epidemic actions as well as an effective response to the COVID-19 epidemic situation;

- The government increased from $15 \%$ to $30 \%$ the available limit from the reserve fund for dealing with disasters (totaling BGN 80 million or EUR 40 million). The limit could be subject to future change;

- The government will support companies with proven impact from the epidemic by covering $60 \%$ of the employees' wages and social security contributions for up to three months. BGN 1 billion (EUR 500 million) were allocated for this measure. (After a financial package from the EU structural funds totaling BGN 870 million (EUR 435 million) will finance the socio-economic measures, including additional 6 remunerations for medical and non-medical 
staff and financial support to SMEs.

During COVID-19 crises continued the increase of all other public expenditure. The aim of the research is the evaluation the effectiveness of public spending and its impact on the Gross Domestic Product before and during the health crises.

\section{Model}

\subsection{Models for testing the impact of public spending on the value of GDP}

It is created an original model for testing of the impact of total public spending, capital, for salary, social insurance and care, for maintenance by the consolidated fiscal program on the value of GDP according to Carvalho et al. (2012).

$$
\operatorname{GDP}_{\mathrm{t}}=\mathrm{a}_{0}+\mathrm{a}_{1} \text { PS total } \mathrm{t}_{\mathrm{t}}+\mathrm{a}_{2} \text { PS total } \mathrm{t}_{-1}+\varepsilon
$$

where

$\mathrm{GDP}_{\mathrm{t}}$-Gross Domestic Product for the current quarter;

PS total $\mathrm{t}_{\mathrm{t}}$-total public spending by the consolidated fiscal program for the current quarter;

PS total $t_{-1}$-total public spending by the consolidated fiscal program for the previous period.

$$
\mathrm{GDP}_{\mathrm{t}}=\mathrm{b}_{0}+\mathrm{b}_{1} \mathrm{SSIC}_{\mathrm{t}}+\mathrm{c}_{1} \mathrm{CPS}_{\mathrm{t}}+\mathrm{d}_{1} \mathrm{MAN}_{\mathrm{t}}+\varepsilon,
$$

where

$\mathrm{GDP}_{\mathrm{t}}$-Gross Domestic Product for the current quarter;

SSIC $_{\mathrm{t}}$-public spending for salary, social insurance and care by the consolidated fiscal program for the current quarter;

$\mathrm{CPS}_{\mathrm{t}}$-capital public spending by the consolidated fiscal program for the current quarter;

$\mathrm{MAN}_{\mathrm{t}}$-public spending for maintenance by the consolidated fiscal program for the current quarter.

\subsection{The variables used in the model}

- GDP-quarterly, the data used for its measurement on the components of Final Consumption Expenditure. This indicator of GDP fully correspondents to public spending as a component of aggregate demand, including consumption, investments, public spending and net export;

- Public spending financed with national funds-quarterly, total, capital spending, for salary, social insurance and care, for maintenance by the consolidated fiscal program.

\subsection{Limitation of research}

- The spending is distinguished by the well-known classification of current and capital according to their economic characteristics;

- Due to the different calculation of variables by the statistics-with or not accumulation, monthly or quarterly-are recalculated the different variables to be mathematically compatible-quarterly, without accumulation and in BGN;

- The survey uses the data of consolidated fiscal program for the period before and after COVID-19 pandemic-2019-2020.

\section{Results}

The Bulgarian economy is small and open. After the transformation to the the market economy 30 years ago, was achieved macroeconomic and financial stability, budget deficit and government debt decreased, the number of bad loans 
was lower compared with previous years. All efforts led to investments climate to be improved. The access to credit became more easy year by year. The Bulgarian National Bank works as Currency Board. Due to it, some instruments of monetary policy have been lost. The fiscal instruments are the main way to stimulation of economic growth. The public spending was an important part of aggregate demand, mainly in the infrastructure projects, encouraging the economic growth. After contracting by $4.2 \%$ in 2020 due to the COVID-19 pandemic, GDP is projected to increase by $3.8 \%$ in 2021 and $4.4 \%$ in 2022 .

The data for the public spending and its changes before and after COVID pandemic are presented below (Figure 1).

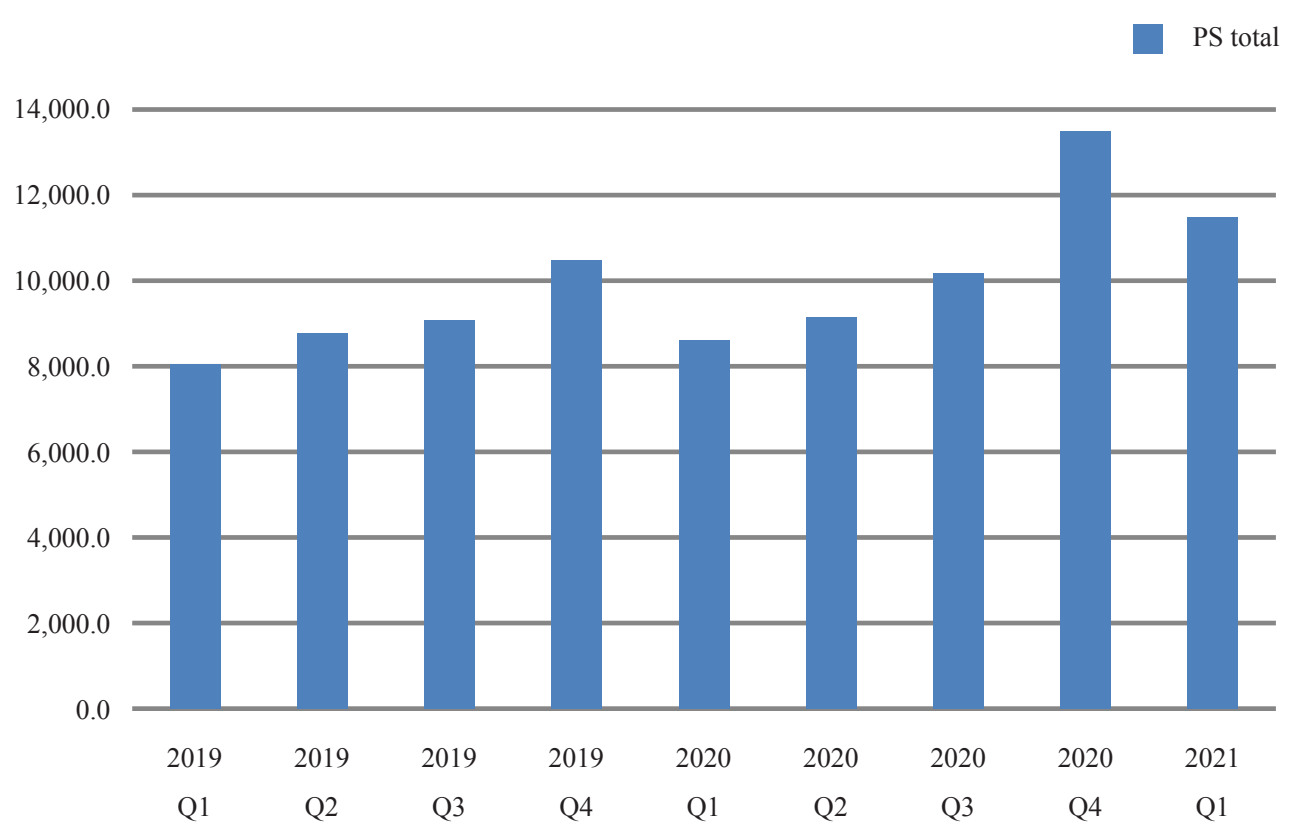

Figure 1. Public Spending total before and after COVID-19 pandemic (mil BGN) Source: https://www.minfin.bg/en/statistics/6; Consolidated Fiscal Program Data (Quarterly)

Table 1. Public spending change during the lockdown (on quarterlybase)

\begin{tabular}{ccccc}
\hline $\begin{array}{c}\text { Public spending changes during the lockdown } \\
\text { (on quarterly base) } \%\end{array}$ & Q1 & Q2 & Q3 & Q4 \\
\hline Total & 2020 & 2020 & 2020 & 2020 \\
\hline $\begin{array}{c}\text { Salary, social insurance and care } \\
\text { Capital public spending }\end{array}$ & -17.95 & 6.26 & 11.30 & 32.60 \\
$\quad$ Maintenance & -80.84 & 42.23 & 65.37 & 76.87 \\
& -40.34 & 6.69 & 7.31 & 136.37 \\
\hline
\end{tabular}

Source: https://www.minfin.bg/en/statistics/6; Consolidated Fiscal Program Data (Quarterly) and own calculation

The new stimulus package from the Government in Bulgaria perhaps the catalyst the changes in public spending during the health crises. By the first lockdown, all public spending decreased at a small pace, only capital expenditure reduced sharply due to uncertainly in the economy. During the second and third quarters of the pandemic 2020, all public spending slowly increased to overcome health crises and negative economic tendencies. During the last quarter of 
2020 the expenditure raise totally with $32.60 \%$. The public cost for capital and maintenance is targeted to the recovery of the economy. The public spending before and after the pandemic are shown above (Table 1).

Before the pandemic, the statistical analysis shows the coefficient of determination for capital spending is more significant compared with all other types of expenditures. On this base, it is confirmed by the economic analyze capital spending has a direct and additional multiplier effect on aggregate demand and on GDP. The impact of the current quarter spending is significant, indicating these costs immediately trigger higher demand for goods and services. As is known from the theory, earnings and profit increase not only in the sectors where public capital expenditure is carried out. This result does not realize only an increase in aggregate demand through its public expenditure element (G), but also indirectly through consumer spending $(\mathrm{C})$.

The economic analysis shows the impact of total spending by the consolidated fiscal program on aggregate supply in the current quarter is strong. For Bulgaria it probably means:

- the unevenness of total spending by consolidated fiscal program quarterly, confirms typical figure for Bulgariaeach year in the fourth quarter there is the largest magnitude of these costs;

- more of the costs are immediately spent. It confirms the high elasticity of consumer spending on income for countries like Bulgaria. Total cost is covered by a significant part of income in a different form. The impact of total public spending on aggregate demand and therefore GDP is reflected and lost within a short timeframe;

- The short time horizon of the economic agents in a country.

After the beginning of the COVID-19 crises the situation is changed.

On Table 2. Model Summary is given the coefficient of determination of the multifactorial regression model. As expected, the coefficient is $\mathrm{R}^{2}=1,000$, which means almost a functional link. Also, the coefficient is statistically significant (Table 3, Sig. $<\alpha=1,10$ ).

Table 2. Model summary

\begin{tabular}{ccccc}
\hline Model & $\mathrm{R}$ & R Square & Adjusted R Square & Std. Error of the Estimate \\
\hline 1 & $1,000^{\mathrm{a}}$ & 1,000 & 1,000 & 39,32 \\
\hline
\end{tabular}

a. Predictors: (Constant), MANt, SSICt, CPSt

Table 3. ANOVA ${ }^{\mathrm{b}}$

\begin{tabular}{cccccc}
\hline Model & Sum of Squares & df & Mean Square & F & Sig. \\
\hline Regression & $45,143,674,275$ & 3 & $15,047,891,425$ & $9,730,130$ & $0,007^{\mathrm{a}}$ \\
Residual & $1,546,525$ & 1 & $1,546,525$ & & \\
Total & $45,145,220,800$ & 4 & & & \\
\hline
\end{tabular}

a. Predictors: (Constant), MANt, SSICt, CPSt

b. Dependent Variable: GDP

In the Table 4. Coefficients-are defined the standardized coefficients for the multifactor regression model for each type of public spending on economic activities during the pandemic of COVID-19. 
Table 4. Coefficients

\begin{tabular}{cccccc}
\hline \multirow{2}{*}{ Model } & \multicolumn{2}{c}{ Unstandardized Coefficients } & Standardized Coefficients & t & Sig. \\
& B & Std. Error & Beta & & \\
\hline (Constant) & $-9,712,590$ & 283,220 & & $-34,293$ & 0,019 \\
SSICt & 5,618 & 0,042 & 1,311 & 133,139 & 0,005 \\
CPSt & 0,678 & 0,071 & 0,146 & 9,606 & 0,066 \\
MANt & $-3,560$ & 0,084 & $-0,620$ & $-42,455$ & 0,015 \\
\hline
\end{tabular}

a. DependentVariable: GDP

The public spending for salary, social insurance and care changed after the pandemic and this spending declines immediately after the lockdown (Figure 2).

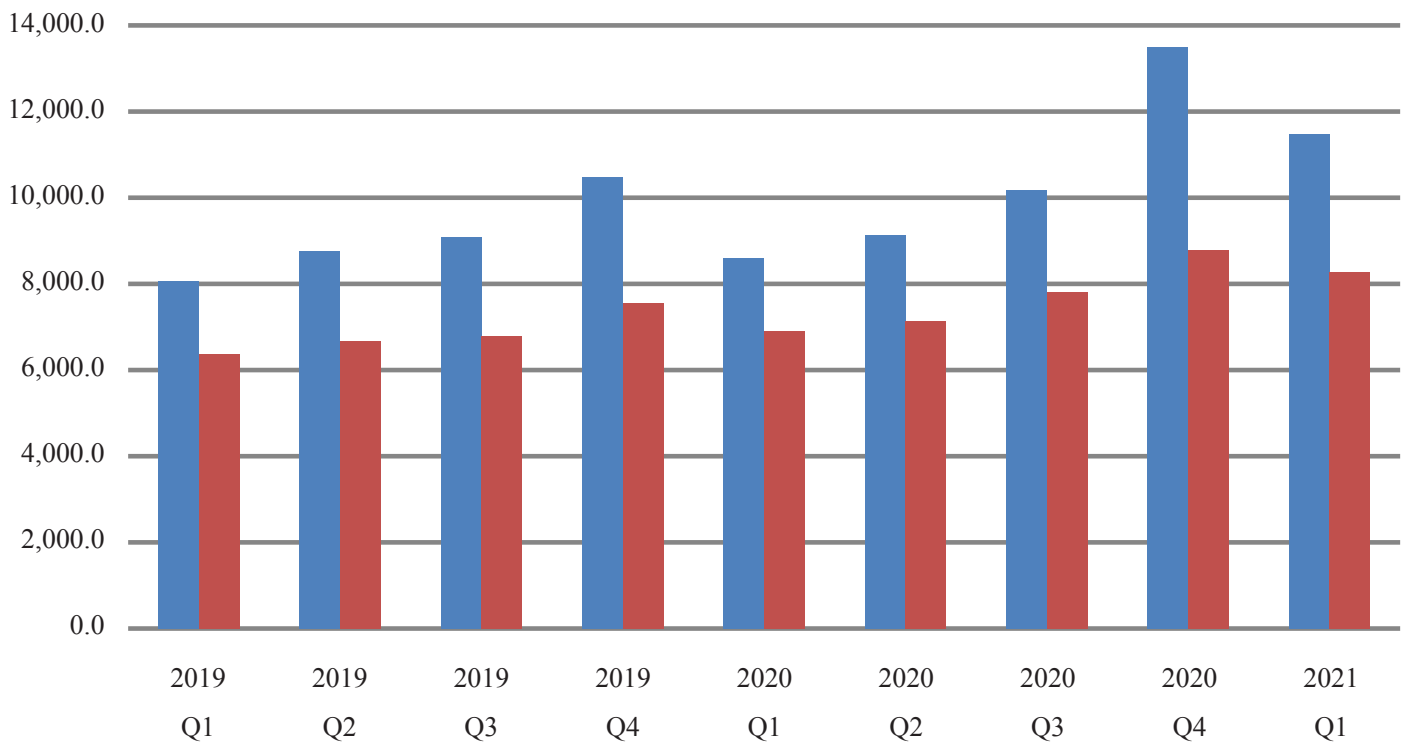

Figure 2. Public spending-total and salary, social insurance and care before and after COVID-19 pandemic (mil BGN) Source: https://www.minfin.bg/en/statistics/6; Consolidated Fiscal Program Data (Quarterly)

By the statistical analysis during the pandemic, the determination of the cost of salary, social insurance and care is highest compared to other costs on GDP. It defers from the impact before the pandemic. The correlation coefficients are absolutely significant. Economic analysis shows for the current quarter, this ratio shows an extremely strong impact of labor costs and social care on aggregate demand. There is also a multiplier effect for other non-public sectors. First, the changes come from the increasing cost of social care. Second, the government compensated the part of lost income in the companies closed during the pandemic. They are mainly in the service sector and tourism. The last is the important sector for the Bulgarian economy. Third, the impact of salary on economic activity confirms the high elasticity of consumption expenditure on income and the high marginal propensity of consumption in the country. The income revenue is transformed in consumer spending through a short period of time and increases aggregate demand without 
time lag. The impact of income received with public funds is lost in a very short period of time and confirms once again the extremely short time horizon of economic agents in the country.

After the first lockdown, capital public spending declined sharply and they recovered slowly third and fourth quarters of 2020 (Figure 3).

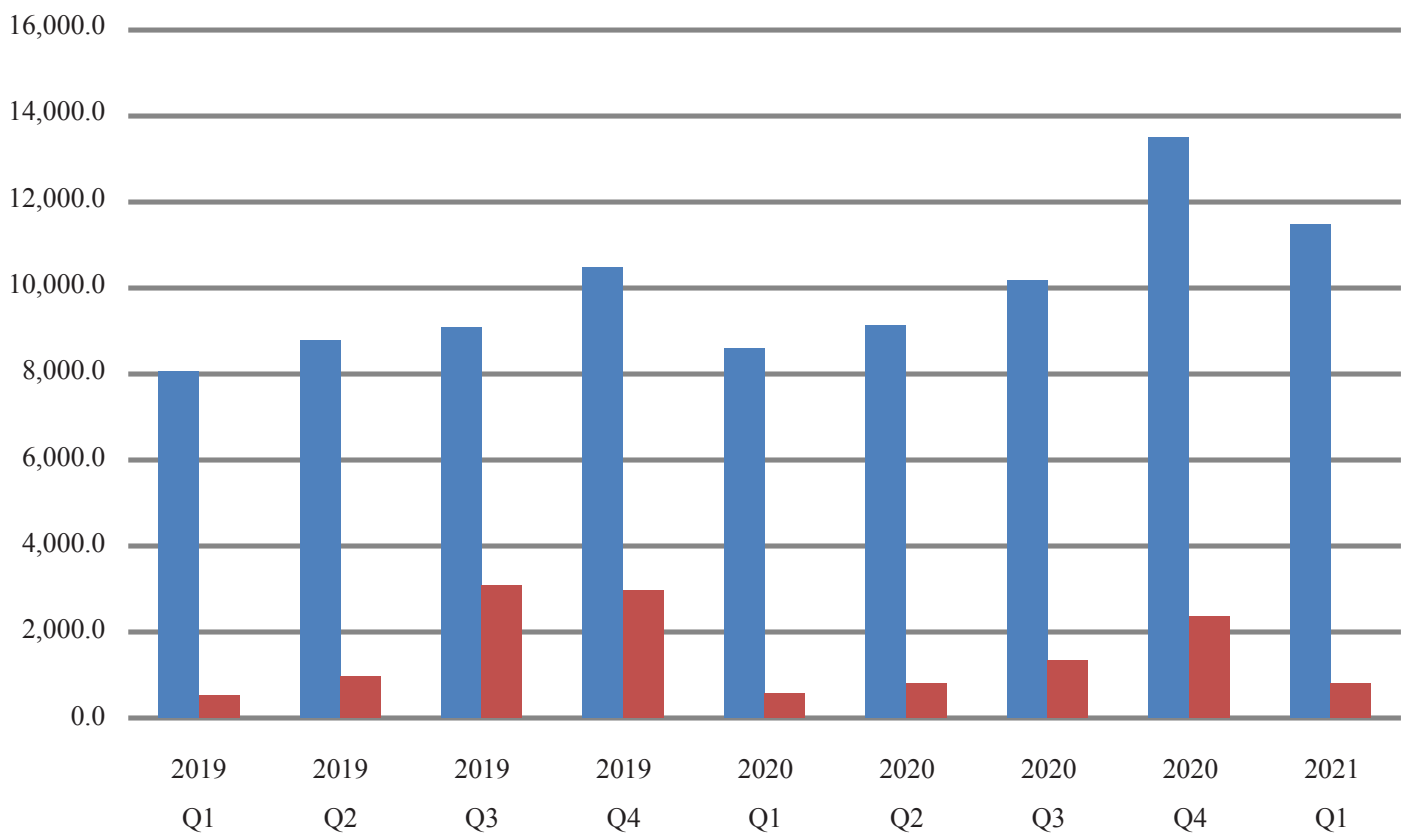

Figure 3. Public spending-total and capital public spending before and after COVID-19 pandemic (mil BGN) Source: https://www.minfin.bg/en/statistics/6; Consolidated Fiscal Program Data (Quarterly)

After the pandemic, the statistical analysis shows the coefficient of determination for capital spending decreases compared with the period before, but continues to influence economic activities. Its role will increase next months by recovery of the economy. The economic analysis confirms the capital spending has a direct and additional multiplier effect on aggregate demand and on GDP. The impact of the current quarter is significant, indicating these costs immediately trigger higher demand for goods and services. As is known from the theory, earnings and profit increase not only in the sectors where public capital expenditure is carried out. The correlation coefficient for the previous quarter is small for Bulgaria. The capital expenditures due to the longer duration of each round of turnover of capital have their impact on aggregate demand and hence on GDP for a longer period of time.

The maintenance includes the type of costs transforming into goods and services and immediately increases aggregate demand. The economic analysis shows the maintenance does not affect significantly the aggregate demand in the country. It confirms the economic agents without a time lag transform the income received in various forms into purchases of goods and services and affect the level of GDP in the same quarter.

\section{Conclusion}

The pandemic of COVID-19 influences all sectors of the economy and life. It caused decreasing of produced GDP and higher unemployment. During the pandemic, the government tried to slow down negative economic results though public spending. 
The new stimulus package from the Government in Bulgaria perhaps the catalyst the changes of public spending during the health crises. By the first lockdown, all public spending decreased with a small pace, only capital expenditure reduced sharply. It was due to uncertainly in the economy.

During the pandemic of COVID-19, it found an extremely strong impact of labor costs and social care on aggregate demand. There is also a multiplier effect for other non-public sectors. The changes come from the increasing cost of social care. The government also compensated the part of lost income in the companies closed during the pandemic. They are mainly in the service sector and tourism. The last is an important sector for the Bulgarian economy. The impact of salary on economic activity confirms the high elasticity of consumption expenditure on income and the high marginal propensity of consumption in the country. After the pandemic coefficient of determination for capital spending decreases compared with the period before, but continues to influence economic activities. Its role will increase next months by recovery of the economy. During the pandemic, public spending total has used as the main instrument to overcome the negative results for the economy. They bring more positive results to be solved health issues, but not for faster recovery of the economy.

\section{Conflict of interest}

The author declares no competing financial interest.

\section{References}

Balibek, E., Paulo, M., John, R., \& Sandeep, S. (2021). Public sector support to firms, special series on fiscal policies to respond to COVID-19. IMF. Special Series on COVID-19. https:/www.imf.org/en/Publications/SPROLLs/ COVID-19-special-notes

Barnichon, R., Debortoli, D., \& Matthes, C. (2020, January). Understanding the size of the government spending multiplier: It's in the sign. FRB San Francisco Working Paper. Economic Studies. https://doi.org/10.24148/ wp2021-01

Carvalho, C., Eusepi, S., \& Grisse, C. (2012). Policy initiatives in the global recession: What did forecasters expert? Federal Reserve Bank of New York. SSRN Electronic Journal, 18(2), 1-11. https://doi.org/10.2139/ssrn.2010647

European Commission Directorate General Economic and Financial Affairs Policy. (2020, May 7). European Commission Directorate General Economic and Financial Affairs Policy measures taken against the spread and impact of the coronavirus. https://ec.europa.eu/info/sites/default/files/coronovirus_policy_measures_7_may.pdf

Kahn, M. E. (2005). The death toll from natural disasters: The role of income, geography, and institutions. Review of Economics and Statistics, 87(2), 271-284. https://doi.org/10.2139/ssrn.391741

Kim, B. H. (2020). Budgetary responses to COVID-19: The case of south Korea. Journal of Public Budgeting, Accounting \& Financial Management, 32(5), 939-947. https://doi.org/10.1108/JPBAFM-06-2020-0079

Lin, T. (2015). Governing natural disasters: State capacity, democracy, and human vulnerability. Social Forces, 93(3), 1267-1300. https://doi.org/10.1093/sf/sou104

Ministry of Finance. (n.d.) Data on the Consolidated Fiscal Program (quarterly). https://www.minfin.bg/en/statistics/6

Raschky, P. A. (2008). Institutions and the losses from natural disasters. Natural Hazards and Earth System Sciences, 8(4), 627-634. https://doi.org/10.5194/nhess-8-627-2008 